\title{
Discontinuation of Work Relationship in the Pandemic Time Covid-19 in Indonesian National Law
}

\author{
Eti Mul Erowati ${ }^{*}$, Ikama Dewi ${ }^{1}$ \\ 1 Universitas Wijayakusuma Purwokerto, Indonesia \\ *e-mail: etimul26@gmail.com
}

Article history: Received 15 December 2020; Accepted 31 March 2021; Available online 30 April 2021

\begin{abstract}
The corona virus pandemic has shaken not only Wuhan, but also the world. This virus has spread widely to almost all countries in a short time. Meanwhile, in Indonesia the corona virus began to be detected when two

Keywords: Employment; Covid-19; Termination of Employment Indonesian citizens (WNI) tested positive for the corona virus on March 1, 2020. The two Indonesians had previously had contact with a foreign national (WNA) from Japan who lived in Malaysia at an event. in Jakara. Based on data up to April 20, 2020, the number of victims due to the corona virus was 6,760 cases. A total of 590 of them died and 747 people were declared cured. Termination of Employment (PHK) is something that is very feared by employees. This is due to the chaotic economic conditions which have an impact on many companies that have to go out of business, and of course have an impact on the unilateral termination of employment by employers. To protect workers' rights due to layoffs, the Government as one of the elements in carrying out industrial relations has provided legal protection guarantees for workers whose employment has been terminated by employers as regulated in Chapter XII, precisely in Article 150-172 of Law Number 13 of 2003 concerning Manpower.
\end{abstract}

Copyright @ Universitas Pendidikan Ganesha. All rights reserved.

\section{Introduction}

Humans were created by God as social beings and will not be able to live alone but need the presence of other humans in order to fulfill their needs. One human being with another human being has various relationships, including social relationships or legal relationships. One example of a legal relationship is a contract / agreement relationship, a legal relationship in a contract or an agreement commonly carried out in the business / individual world, the agreement / contact relationship creates an agreement between the parties that make it.

According to Indonesian law an agreement is the same as a contract or agreement, but according to the common law system an agreement is different from a contact. Agreement has a broader meaning than a contract because the agreement includes legal relations that are public in nature, while the contract includes only private legal relationships. Judging from the subject, many agreements in society are carried out by, among others, between human beings, between legal entities, as well as between humans and legal entities, while in terms of their various types, there are agreements regulated in the Civil Code which are called nominates, among others. : sale and purchase agreement, payable agreement. 
Borrowing and borrowing agreements, power granting agreements, and agreements arising from developments in the community that are not regulated in the Civil Code are called anonymous agreements (innominate), including: franchise agreements (francaise), financing agreements (leasing, venture capital, factoring, consumer financing, credit cards, etc.) The above agreements will be considered valid if they meet the requirements stated in article 1320 of the Civil Code, namely: 1) there must be an agreement between the two parties; 2) each party must be legally competent; 3 ) there must be an object and 4) must have a lawful cause (not against the law, public order and morals.

An agreement that has been legally made is binding and applies as law to the parties who made it, therefore both parties must implement or obey it (the principle of Pacta sunservanda), but sometimes the agreement made legally cannot be implemented properly because there are various things that influence it. For example, many agreements cannot be implemented during the current Covid-19 pandemic.

The impact of COVID-19 not only disrupts Indonesia's export and import sectors, but also attacks the trade sector, namely from decreased tax revenue. This has a very serious impact because in the trade sector tax revenue has a very big contribution in boosting state revenue to be precise, which is in the second largest position (Sugarda \& Rifky, 2017). The Central Bureau of Statistics (BPS) released data related to oil and gas and non-oil and gas exports which stated that the decline in oil and gas and non-oil and gas exports, the impact of which was caused by this pandemic, is not surprising because China is indeed the largest crude oil importer in the world. Not only that, the COVID-19 pandemic has also caused a decline in production produced by China, even though the focus of world goods and central production of world goods is centered in China. If there is a negative correction to production in China, the world will experience supply chain disruptions which in turn can reduce the world production process whose raw materials are imported from China. The Indonesian state itself desperately needs raw materials from China to carry out the production process, especially raw materials for electronic parts, furniture, plastics, textiles and computers.

The impact of COVID-19 on the tourism sector is also not free from threats. Data compiled from the Central Statistics Agency explained that in 2019 foreign tourists from China who came to Indonesia touched the figure of 2.07 million tourists or $12.8 \%$ of the total number of foreign tourists throughout 2019. The COVID-19 pandemic has resulted in a decline in tourists coming to Indonesia. Tourism supporting sectors, namely restaurants, hotels and retailers, have also been affected by the COVID-19 pandemic. Hotel profits have decreased by up to $40 \%$, which has an impact on hotel operations and threatens its business continuity. The decline in foreign visitors also affects the income of a restaurant or restaurant whose customers are more dominant than visitors from abroad (Block, 2017). Weak tourism growth also has an impact on the retail industry. The areas whose retail sector is most affected are Jakarta, Medan, Bangka Belitung, Riau Islands, Manado and Bali. The COVID-19 pandemic is also expected to affect the micro, small and medium business sector, this is because foreign visitors who come to a destination will usually buy souvenirs to take home (Iswahyudi, 2016). If foreign visitors who visit decline, it is certain that income from micro, small and medium enterprises will also decrease (Saidi et al, 2017). Bank Indonesia has released data in 2016 related to the micro, small and medium business sector which states that micro, small and medium enterprises are very dominant in business units in Indonesia and the type of micro business is able to absorb a lot of workforce.

The COVID-19 pandemic does not only have a horror impact, but can also have a good impact on the Indonesian economy. Among them, new export markets other than China could have great opportunities to enter Indonesia. In addition, the domestic economy will also be boosted more because the government will further strengthen domestic production rather than take profits from foreign parties. The COVID-19 pandemic can also be used as a correction so that investment can be stable even though the global economy is under threat. 
To protect workers' rights due to layoffs, the Government as one of the elements in carrying out industrial relations has provided legal protection guarantees for workers whose employment has been terminated by employers as regulated in Chapter XII, precisely in Articles 150-172 of Law Number 13 of 2003 concerning Manpower (hereinafter referred to as the Manpower Law). As a basic rule in the manpower sector, the Manpower Law does not only regulate the implementation of industrial relations since the establishment of industrial relations, but also regulates the termination of industrial relations. which is built between workers and employers. Based on the background of the above problems, the following problems can be formulated, can the corona pandemic be used as an excuse for termination of employment by companies?

\section{Method}

The research method used in writing this article is the normative legal research method. This research uses a statutory approach. In particular, research in labor law will examine the perspective of conventions/agreements as the main source of law in civil law, the Case Approach, namely by examining the termination of employment during Covid-19. This legal research uses sources of legal materials including: labor law as primary legal material, as well as various literature, journals, various researches and developing doctrines related to termination of employment during Covid-19 as secondary legal material and dictionaries as tertiary legal materials. The collection of legal materials is done by using document study techniques. Legal materials that have been collected will be analyzed using descriptive techniques, evaluation and argumentation, so that they can obtain relevant answers to the problems discussed in this paper.

\section{Result and Discussion}

\section{Definition of Agreement}

An agreement according to Article 1313 of the Civil Code is an act in which one person / more binds himself to one / more person. From this incident arose a legal consequence between two / more people called an agreement in which there are rights and obligations of each party to the agreement that must be valid, that is, has fulfilled the legal condition s of the agreement as in article 1320 of the Civil Code, among others: freedom of contract (Article 1338 of the Civil Code), the parties are free to make the contents of the contract according to the interests of the parties desired.

The freedom to determine the contents of the agreement according to Article 1337 of the Civil Code is limited by the provision that "must have a lawful cause", that is, it does not conflict with Law, public order and morals. Free in member agreements means no coercion, fraud, oversight or abuse of circumstances. Each of the parties to the agreement must be legally competent, namely the ability of a person to carry out legal actions in the field of civil law, and therefore be able to account for the legal consequences, including people who are adults, not under the authority and people who are deemed by law cakap.20 The object in an agreement also absolutely must exist, if there is no object it means that there is no agreement and the contents of the agreement must not conflict with law, public order or morals.

An agreement made legally can be carried out by the parties, namely the parties can fulfill the rights and obligations that have been agreed to achieve the objectives of the agreement. In fact, not all agreements made legally can be implemented, sometimes one of the parties cannot carry out the agreement due to default or overmacht / force mejeur / coercive circumstances. Default or termed default is a situation that occurs because one party does not fulfill its obligation or allows a situation to take place in such a way (non-performance) that the other party. 


\section{The Covid-19 pandemic in Indonesia}

The Covid 19 pandemic is a pandemic of the coronavirus disease that is currently taking place in 2019 (Covid-19) which is caused by the acute respiratory syndrome coronavirus 2 (SARS-CoV-2). The Covid 19 pandemic has hit almost the entire world, including the State of Indonesia which was only discovered in February 2020 until now and the transmission has developed quite rapidly, based on data updates as of May 22, 2020, Indonesian people who have been affected are 20,796 people, who have recovered 5,057 people and 1,326 people died, this is an accumulation of additions every day since the discovery of the first person who tested positive for Covid-19.

The number is increasing every day. On April 13, 2020, the government has stipulated Presidential Decree No. 12/2020 concerning the Determination of Non-Natural Disasters due to the spread of Covid-19. The Covid 19 pandemic has a tremendous impact on human life, namely a very serious impact on health and can cause death, in addition to the health impact it also has an impact on the economies of countries around the world, including Indonesia. Among other things, the delay in the production process, due to the increasing scarcity of raw materials, especially those from imports which had been stopped, the tourism, entertainment and hospitality and aviation industries were stopped due to the policy of social restrictions and area closures, as a result there were many industries that reduced their employees which resulted in temporary layoffs. employees, and even layoffs (PHK), which can result in decreased income and increased unemployment and increased crime.

In the informal sector it is also very affected, namely the lack of consumers (because the purchasing power of the community has decreased / people deliberately reduce their spending because they are afraid of being infected or because there is a ban from the government as one of the implementation of PSBB), the loneliness of consumers causes reduced income or even no income at all. In the industrial community or people in the informal sector, usually in the provision of capital, they often enter into loan agreements with other parties (either through banking or non-bank institutions), so that on the one hand they still have the obligation to repay the loan. Based on article 1338 paragraph (1) of the Civil Code that all agreements made legally are valid as laws for those who make them, it means that the agreement is binding and must be obeyed by the parties (according to the principle of pacta sunservanda), but there are several obstacles for the community (industry / individuals) in carrying out the agreement.

Among others, as follows: 1). economic constraints During the Covid 19 pandemic, industrial communities or ordinary people generally have different economic or financial conditions because they are affected by Non-Natural Disasters due to the spread of Covid-19. For the health industry, the food industry, the telecommunications industry, and other industries that are very much needed by the community during a pandemic, they may not have an impact on their economic capacity, but there are industries that have an impact on economic capacity due to the Covid 19 pandemic, for example the hotel industry, clothing industry, transportation industry, etc., this also happens to individual communities, civil servants, BUMN employees, employees whose companies are not engaged in a business that still exists amid the Covid pandemic has not had a significant impact on their economic capacity, but for individual communities who have lost their jobs due to reduction Employees / layoffs, people who work in the informal sector have experienced a very drastic decline in turnover due to the Covid 19 pandemic, such as MSMEs, motorbike taxi / grab drivers, will greatly impact their economic capacity.

\section{Termination of Employment During Covid-19}

Termination of Employment (PHK) is something that is very feared by employees. This is due to the chaotic economic conditions which have an impact on many companies that have to 
go out of business, and of course have an impact on the unilateral termination of employment by employers. Umar Kasim also explained that layoffs are a sensitive issue, employers should be wise in laying off workers, considering layoffs can reduce people's welfare, people lose their jobs, even more serious layoffs can lead to unemployment. So that what is mandated by Article 27 paragraph (2) of the 1945 Constitution of the Republic of Indonesia (hereinafter referred to as the 1945 Constitution) that every citizen has the right to work and a decent living for humanity is not achieved. To protect workers' rights due to layoffs, the Government as one of the elements in carrying out industrial relations has provided legal protection guarantees for workers whose employment has been terminated by employers as regulated in Chapter XII, precisely in Articles 150-172 of Law Number 13 of 2003 concerning Manpower.

An employment relationship is basically a relationship between the worker and the employer after the existence of a work agreement, which is an agreement in which the first party, the worker binds himself to the other party, the employer to work for a wage and the employer declares his ability to employ the worker by paying wages. Article 1 point 15 of the Manpower Law describes a work relationship as a relationship between an entrepreneur and a worker / laborer based on a work agreement, which has elements of work, wages and orders. This is also confirmed in Article 50 of the Manpower Law which states that a work relationship occurs because of a work agreement between an entrepreneur and a worker / laborer. The employment relationship then creates rights and obligations that must be fulfilled by each party (entrepreneur and worker / laborer).

Today, issues regarding employment are very complex and diverse. This is due to the fact that the working relationship between employers and workers does not always run harmoniously, but there are often various turmoil and tensions. Tensions between workers and employers often lead to industrial relations disputes, which sometimes lead to layoffs by employers against workers.

Since the spread of the corona pandemic in Indonesia, this has had an impact on almost all sectors including health, economy, industry and social. The decrease in the number of production automatically reduces the income earned by the company. As a result, some employers find it difficult to manage their finances, including to meet operational costs, one of which is paying for workers' normative rights such as wages. The difficulties faced then encourage employers to take efficiency measures as a form of loss mitigation such as laying off workers, and even terminating employment (layoffs) that harm workers. In addition to efficiency reasons, the losses suffered by companies due to the corona pandemic were also considered a force majure event which later became a reason for layoffs.

Companies cannot immediately lay off due to loss, force majeure or efficiency due to a pandemic and activity restrictions that can harm the company. Article 164 paragraph (1) of the Manpower Law states that:

"Entrepreneurs can terminate the employment relationship of workers / laborers because the company is closed because the company has suffered continuous losses for 2 (two) years, or a force majeure, provided that the worker / laborer is entitled to severance pay of 1 (one). ) times the provisions of Article 156 paragraph (2) the reward money for the service period is 1 (one) time the provisions of Article 156 paragraph (3) and rights compensation money according to the provisions of Article 156 paragraph (4). "

Based on these provisions, it can be seen that the company can make layoffs if they experience a loss or force majeure. Layoffs made on the grounds of a forece majeure, while what is meant by force majeure in the Manpower Law does not explain, but is generally regulated in Articles 1244 and 1245 of the Civil Code.

It is possible for entrepreneurs to use the corona pandemic as an excuse for force majeure to carry out layoffs given the large influence it has on the company's operational 
activities. The constraints in operational activities have an impact on company income, as a result the company has difficulty in paying workers' wages which are its obligations. In addition, the corona pandemic can be categorized as an unexpected event because it arises beyond the control of the parties so that it does not have the ability to prevent it. When viewed from the point of view of the time period for the conditions to take effect, the corona pandemic is included in a temporary force majeure considering that the inability of entrepreneurs to carry out their obligations is only temporary until things return to normal. The existence of a Government policy that has determined the corona pandemic as a national disaster and the issuance of a number of legal products can strengthen the reasons for entrepreneurs to declare the corona pandemic as an event that creates a force majeure because it explicitly concludes that the corona pandemic is categorized as a national non-natural disaster.

Companies that can no longer survive the impact of the corona pandemic then choose to close or close part of their business units and even have to lay off workers as a form of efficiency as well as to reduce company spending so that it can return to stability. Layoffs on the basis of efficiency in the Manpower Law are regulated in Article 164 paragraph (3) which explains that: "Entrepreneurs can terminate their employment because the company closes not because they have suffered a loss for 2 (two) consecutive years or not because of a force forward. However, the company conducts efficiency with the provision that Workers are entitled to severance pay of 2 (two) times the provisions of Article 156 paragraph (2), the reward money for working period of 2 (two) times the provisions of Article 156 paragraph (2), the reward money for working period of 1 one) time the provisions of Article 156 paragraph (3) and compensation for rights according to the provisions of Article 156 paragraph (4) ".

\section{Conclusion}

There are a number of different scenarios that employers can consider in response to layoffs during COVID-19. This includes the complete closure of the business because it is no longer financially viable and the redundancy of all employees, or laying off only part of the employee. Based on the Manpower Act, layoffs can basically only be done when there is a business closure (including partial closure or reduction of all business activities), either preceded by or without loss for two consecutive years (this is relevant for determining the right to terminate employment). Will force majeure be an acceptable reason for termination of employment by paying a minimum severance pay? If the business is not closed, employee termination can still be made but only with the written consent of the employee through a mutual termination agreement. Note that without the agreement, proposed terminations will be considered disputes and can only be resolved through a labor court, a process that can take six months or more, during which the employee's salary must be paid. Note that Indonesia does not recognize the termination notification concept. Unless a collective termination agreement is reached.

It is possible for entrepreneurs to use the corona pandemic as an excuse for force majeure to carry out layoffs, given the large influence it has on company operations. In addition, the corona pandemic is also categorized as a force majeure event considering its unexpected nature because it arises outside the control of the parties. The existence of a government policy that defines the corona pandemic as a national disaster and the issuance of a number of legal regulations strengthen the reasons for entrepreneurs to declare the corona pandemic a force majeure event because it explicitly concludes that the corona pandemic is categorized as a national non-natural disaster. In addition to force majeure reasons, efficiency is also a reason for layoffs, but in practice this is still a polemic considering there are two different interpretations of the meaning of the provisions of Article 164 paragraph (3) of the Manpower Law. If it is based on the Constitutional Court decision Number 19 / PUU-IX / 2011. 


\section{Daftar Pustaka}

Akhmad, Romadhoni, B., Karim, K., Tajibu, M. J., \& Syukur, M. (2019). The Impact of Fuel Oil Price Fluctuations on Indonesia's Macro Economic Condition. International Journal of Energy Economics and Policy, 9(2), 277-282. https://doi.org/10.32479/ijeep.7470

Block, D. (2017). Political Economy in Applied Linguistics Research. In Language Teaching (Vol. 50). https://doi.org/10.1017/S0261444816000288

Carrillo-Larco, R. M., \& Castillo-Cara, M. (2020). Using Country-Level Variables to Classify Countries According to The Number of Confirmed COVID-19 Cases: An Unsupervised Machine Learning Approach. Wellcome Open Research, Maret (31), 1-8. https://doi.org/10.12688/wellcomeopenres.15819.1

Ghozali, I. (2011). Aplikasi analisis multivariate dengan program IBM SPSS 19. In Badan Penerbit Universitas Diponegoro. Semarang.

Ghozali, I. (2016). Statistik Non-Parametrik: Teori dan Aplikasi dengan Program SPSS. In Universitas Diponegoro. https://doi.org/10.1002/14651858.CD002812

Hinrichs, U., Carpendale, S., Knudsen, S., \& Thudt, A. (2017). Analyzing qualitative data. Proceedings of the 2017 ACM International Conference on Interactive Surfaces and Spaces, ISS 2017. https://doi.org/10.1145/3132272.3135087

Hua, J., \& Shaw, R. (2020). Corona Virus (COVID-19) "Infodemic" and Emerging Issues through a Data Lens: The Case of China. International Journal of Environmental Research and Public Health, 17(7), 2309. https://doi.org/10.3390/ijerph17072309

Iswahyudi, H. (2016). Back to Oil: Indonesia Economic Growth After Asian Financial Crisis. Economic Journal of Emerging Markets, 8(1), 25-44. https://doi.org/10.20885/ejem.vol8.iss1.art3

Iswahyudi, H. (2018). Do Tax Structures Affect Indonesia's Economic Growth? Journal of Indonesian Economy and Business, 33(3), 216-242.

Undang-Undang Dasar Negara Republik Indonesia Tahun 1945 Undang-Undang Nomor 13 Tahun 2003 Tentang Ketenagakerjaan

Kitab Undang-Undang Hukum Perdata Undang-Undang Republik Indonesia Nomor 24 Tahun 2007 Tentang Penanggulangan Bencana

Peraturan Pemerintah Nomor 21 Tahun 2020 tentang Pembatasan Sosial Berskala Besar Dalam Rangka Percepatan Penanganan Corona Virus Disease 2019 (COVID-19)

Keputusan Presiden Nomor 11 Tahun 2020 tentang Penetapan Kedaruratan Kesehatan Masyarakat Corona Virus Disease 2019 (COVID-19). 